\title{
How to Improve Effectiveness of Renewable Space Heating Programs by Better Understanding Homeowner-Installer Interactions
}

\author{
Alisa Freyre ${ }^{1,2, \dagger}$, Stefano Cozza ${ }^{1, *,+}$, Matthias Rüetschi ${ }^{2}$, Meinrad Bürer ${ }^{3}$, Marlyne Sahakian ${ }^{4}$ \\ and Martin K. Patel ${ }^{1}$ \\ 1 Energy Efficiency Group, Institute for Environmental Sciences (ISE), University of Geneva, \\ 1205 Geneva, Switzerland; alisa.yushchenko@unige.ch (A.F.); martin.patel@unige.ch (M.K.P.) \\ 2 Services Industriels de Genève, 1219 Geneva, Switzerland; matthias.ruetschi@sig-ge.ch \\ 3 Research \& Development, EcoAct, 75008 Paris, France; meinrad.burer@eco-act.com \\ 4 Sociology Department, Faculty of Social Sciences, University of Geneva, 1205 Geneva, Switzerland; \\ Marlyne.Sahakian@unige.ch \\ * Correspondence: Stefano.cozza@unige.ch; Tel.: +41-223790652 \\ + Equal contribution.
}

check for

updates

Citation: Freyre, A.; Cozza, S.;

Rüetschi, M.; Bürer, M.; Sahakian, M.;

Patel, M.K. How to Improve

Effectiveness of Renewable Space

Heating Programs by Better

Understanding

Homeowner-Installer Interactions.

Energies 2021, 14, 4625. https://

doi.org/10.3390/en14154625

Academic Editor: Monica Siroux

Received: 21 May 2021

Accepted: 17 July 2021

Published: 30 July 2021

Publisher's Note: MDPI stays neutral with regard to jurisdictional claims in published maps and institutional affiliations.

Copyright: (c) 2021 by the authors. Licensee MDPI, Basel, Switzerland. This article is an open access article distributed under the terms and conditions of the Creative Commons Attribution (CC BY) license (https:/ / creativecommons.org/licenses/by/ $4.0 /)$

\begin{abstract}
In this paper, we perform a literature review on the current state of knowledge about homeowners in the context of the adoption of renewable heating systems. Despite a considerable number of studies about homeowners, homeowner-installer interactions, and ways to improve the effectiveness of renewable heating programs, based on homeowner knowledge, have not yet been studied in much detail. To address these knowledge gaps, we conduct a qualitative study on single-family house owners who installed heat pumps and took part in a renewable heating program in Geneva, Switzerland. We cover homeowner practices in choosing installers and heating system types, homeowners' feedback about heat pump installation and use, as well as their experience in participation in the renewable heating program. Based on the literature review and the findings from the interviews, we provide the following recommendations on how to increase the effectiveness of renewable heating programs: (a) support for homeowners should not be limited to financial incentives; (b) partnership programs with installers could help to increase the quality of installation services and enable homeowners to choose qualified installers; and (c) assisting homeowners in pre-qualification and ex-post analysis, in learning how to operate their renewable heating systems and in solving problems during the post-installation period, can contribute to improved technology reputation, which can, in turn, increase technology uptake by other homeowners.
\end{abstract}

Keywords: renewable heating; heat pumps; homeowners; installers; energy programs; subsidies

\section{Introduction}

Renewable energy development is among the top energy policy issues in a wide range of countries [1-6]. Historically, most attention and financing was devoted to renewable electricity, and the implementation of renewables for electricity generation has been advancing more quickly than for heat $[7,8]$. However, driven by the adoption of greenhouse gases (GHG) emission reduction targets, policy-makers and academia have been taking increased interest in renewable heat supply in buildings $[9,10]$. It has been recognized that accounting for homeowner preferences is essential to successfully promote renewable energy and energy-efficient technologies [11-13]. A proper understanding of how renewable space heating systems are adopted is especially important, given the long lifetime of the respective equipment [14]. Once a new heating system has been installed, it is unlikely that it will be replaced within the subsequent 20 years or even longer [12,15].

A number of studies have demonstrated the importance of homeowner awareness and technology reputation on homeowner choice of heating system type [9,16-18]. Against this 
background, the question of technology reliability and quality of advice, and installation and maintenance services provided by the installers become very important. Moreover, despite a considerable number of homeowner studies [19] (Section 2), the role of installers for the uptake of renewable space heating systems has not yet been studied in detail [20,21].

In this paper, we aim to better understand the interactions among homeowners, installers, and renewable space heating programs, in order to identify opportunities for the increased effectiveness of these programs. We perform a qualitative study of single-family house owners who installed heat pumps and received financial incentives from the renewable heating program Chaleur renouvelable (Literal translation of "Chaleur renouvelable": Renewable heat.) in Geneva, Switzerland. More specifically, we ask the following questions: Which information sources do homeowners use when choosing an installer? Which factors determine the choice of installers? How do interactions with installers impact homeowner satisfaction with the choice of renewable heating system? How could installers be included in renewable heating programs with the objective of increasing renewable heating technology uptake? To answer these questions, we explored the interactions between homeowners and installers, by performing a real-case qualitative study of single-family house owners who installed heat pumps in Geneva, Switzerland (while most existing literature refers to hypothetical circumstances [12,16,22-25]). The results confirm and expand the findings from the literature review, highlighting that installers have a large impact on individual homeowners and technology reputation, and therefore the efficiency of energy programs can be increased through partnership with installers.

We first provide a detailed literature review of the existing knowledge on the views, decision process, and experience of homeowners (Section 2), followed by a description of the case study and the applied method (Section 3). We further present the results (Section 4) and discuss them, with regard to the findings from the literature review and research questions (Section 5). Finally, we give recommendations on how to improve the effectiveness of renewable heating programs (Section 6).

\section{Current State of Knowledge about Homeowners in the Context of Renewable Heating Systems Adoption}

\subsection{Homeowner Awareness and Willingness to Install a Renewable Heating System}

In general, homeowner awareness about renewable heating solutions is low $[16,17,22]$. Moreover, an even lower share of homeowners consider the opportunity to install renewable heating system in their homes [16]. Homeowners with a higher level of education, job, or interests related to the environment or technology are more likely to know about [16], and to choose [17], renewable heating technologies, including heat pumps. It has been demonstrated that middle-aged persons (about 35-45 years old) are more likely to choose renewable heating systems, while the younger population is less involved in such decisions, and the elder population is less willing to take long-term investment decisions, and tends to avoid discomfort related to heating system replacement efforts $[16,26]$. The majority of studies demonstrate a statistically significant positive relationship between income and a willingness to install an innovative heating system $[17,25]$. Lower-income households face a lack of financial resources and are unwilling to incur the additional debt that is related to the installation of an innovative heating system [9]. However, there are also studies demonstrating a negative correlation between income and willingness to consider installation of a renewable heating system, such as a heat pump [16]. Such phenomena may be explained by the wish of lower-income households to reduce their energy costs. However, these findings are related to hypothetical choice surveys and not the real behavior.

\subsection{Information Sources Used by Homeowners}

There are a variety of information sources that homeowners use to choose their heating system type. These sources can be separated into the following two categories: external (i.e., media sources) and internal (i.e., social circles and professionals) [27]. External sources include the internet, TV programs and printed media, and are more important in the early 
stages of technology adoption (i.e., for relatively new technologies) [16,28]. Internal sources include social circles, such as family, friends, and neighbors, but also professionals, such as installers and energy advisers [16]. The choice of information sources may depend on the reason for which homeowners need a new heating system (i.e., problem with previous heating system, decision to renovate or new construction) [26]. According to the majority of the related studies $[9,18]$, internal information sources are generally considered as the most trusted and widely used [22,24], especially in the earlier stages of technology adoption [27,29]. However, fewer publications have shown the relatively low importance of social circles [16] and local authority energy advisers [27] as influencing factors for homeowner choice (these types of findings should be treated with caution as they could be location-specific.).

A few studies have specifically shown that installers have important influence on the choice of heating system technology $[19,20]$. Also, installers have an important impact on technology reputation $[27,30]$. There have been, and still are, problems with the quality of some renewable heating technologies and installation services that are provided, which lead to the bad reputation of some solutions, and therefore create additional barriers for their adoption $[9,27]$. Some renewable heating programs provide training support to installers, to increase the quality of their services [27]. However, a deeper understanding of homeowner-installer interactions could enable renewable heating programs to develop additional measures for increasing the accessibility of high-quality installation services for homeowners. Despite the significance of the topic, there is a notable knowledge gap on how homeowners choose their installers, with only few studies demonstrating the importance of provided services $[9,17]$ and proximity $[28,31]$ criteria.

\subsection{Factors Influencing the Choice of a Heating System}

A number of studies have demonstrated that there is considerable inertia in the decision making related to the choice of the type of heating system $[25,27]$. The underlying reason is that homeowners are, in general, satisfied and accustomed to their heating systems. Changing to another heating system typically calls for efforts to change the user behavior and is considered as being subject to uncertainties, with regard to reliability, performance, and the other characteristics of a new system [27]. Homeowners are more likely to consider choosing an innovative heating system if they are dissatisfied with their previous one, or if the new system is advantageous, with regard to economic and technical aspects (i.e., heating costs, reliability) [27].

The choice of a heating system type is determined by economic, environmental and technical factors, as well as considerations of comfort and aesthetics [12,16,32]. Among the major economic factors are the current $[17,22]$ and expected energy prices $[28,33]$, initial investment costs [24,25,27], and maintenance [29,31,34] and operation costs [33-35]. Significant installation costs are another important barrier to renewable heating technology uptake [9,35]. Subsidies [36,37], fiscal incentives [9,14] and low-interest loans [38] are considered to be important means of support, allowing a reduction in the upfront costs for homeowners. However, in practice, subsidies for costly technologies, such as heat pumps, are typically relatively low compared to the total amount of initial investment, which leads to high free-ridership in renewable heating programs [12,39]. On the other hand, the role of subsidies is wider than investment cost reduction [40]. They reinforce communication about new technologies and influence homeowner behavior on an emotional (i.e., psychological and cognitive) level, thereby helping to improve homeowner attitudes towards new technology options and endorsing their choice [21]. Another economic factor facilitating the choice of renewable heating systems is the increased market value of the house [27,32-37]. Apart from economic considerations, homeowner behavior is driven by a wide variety of other factors [41], including social norms around indoor microclimates that vary in different contexts [42,43]. When choosing a heating system, homeowners consider comfort aspects related to installation (i.e., time and efforts required) [16,24], operation and maintenance (i.e., easiness of handling, cleanliness, independence from 
fossil fuels) [31,34,38], as well as the quality of the heating service provided (i.e., indoor temperature, indoor air quality) [11,27]. Homeowners also consider technical factors, such as functional reliability $[28,35]$, security during operation [16], security of the fuel supply [22,39], energy consumption [17,27], as well as resource availability (for example, forest ownership in the case of wood-based systems) $[25,28]$. Environmental reasoning $[12,25,33]$ and the willingness to improve energy efficiency [38,44] support homeowners' choices of renewable heating systems. However, environmental and efficiency arguments are often discovered to be of secondary importance, supporting homeowner decisions made for the other reasons mentioned above [11,27].

When interpreting the results of homeowner studies, it is important to make a clear distinction between heating system choice for existing buildings [25] and new constructions [26]. In the case of new constructions, the uptake of renewable technologies is higher due to lower costs and better performance of the technologies (i.e., heat pumps in wellinsulated buildings), as well as the lower importance given by homeowners to the cost of the heating system (i.e., it is just one part of the total cost of construction) [12]. In some cases, homeowners cannot choose their heating system type, as this decision is made by the project developer [12]. In existing buildings, homeowners pay more attention to the costs of the heating system and can freely choose the system type (unless when restricted by legislative requirements or technical constraints) [45].

\subsection{Knowledge about Post-Installation Period}

Less research has been conducted on homeowners during the post-installation period $[18,46]$. The influence of economic performance on homeowner satisfaction with their investment decisions is not evident. It has been shown that homeowners hardly carry out any post-installation evaluations based on calculations, and hardly consider the indicators used by installers for selling their heating solutions (e.g., rate of return) [17]. Homeowners can be dissatisfied with their decisions to install renewable heating systems, for economic reasons (e.g., due to high investment and operational costs) [31]. However, homeowner satisfaction seems to be rather determined by their perception of economic factors, more on an emotional level. For example, Bjørnstad demonstrated that homeowner satisfaction with heat pumps investment did not depend on the fact that these systems were economically attractive [17]. The main economic factor influencing homeowner perception was the operational cost, determined by the energy prices [17]. Homeowners tended to be more satisfied with their investment decision if the prices of the energy used for conventional technologies (e.g., oil and gas) were higher. An explanation could be that prices are easy to follow, which is not the case for other parameters [11]. Energy prices determine not only homeowner satisfaction, but also behavior. It has been demonstrated that low operational costs of heat pumps increase the risk of rebound effects and wasteful environmental behavior [11]. Homeowner satisfaction after the installation of a new type of heating system can also be influenced by non-economic factors, such as the technical quality of the equipment [17,31], and comfort (i.e., indoor temperature, air quality) [47]. The easiness to understand and operate the heating system is also important [11,48]. It has been shown that it is related to the level of homeowner engagement with the technology, varying from no to active participation, including installation and system optimization [11] This can be explained by different attitudes towards the technology (e.g., presence of fear versus interest), and supportive information that homeowners receive (e.g., quality of explanation by installer) [11]. Few studies have shown that, in practice, installer-homeowner communication focusses primarily on the economic aspects of renewable heating solutions, while non-economic considerations and aspects of understanding and learning how to operate the systems are rather neglected [11]. In addition, installers do not always provide high-quality post-installation services, in terms of information support and system maintenance $[17,31]$. In such cases, households may face difficulties and discomfort with a renewable heating system, which, as mentioned in Section 2.2, can lead to a bad reputation of the respective technologies, and lower their uptake by other homeowners [11]. 


\section{Method and Data}

\subsection{Case Study}

Switzerland has adopted the climate policy target to reduce carbon emissions in buildings by $50 \%$ (or 6.84 million $\mathrm{t} \mathrm{CO}_{2}$ ) by 2030 compared to 1990 [6,49,50]. A number of policy instruments have been put in place to reach this target, including a carbon tax, building codes and the federal energy program Programme Bâtiments (Literal translation of "Programme Bâtiment" from French to English: "Building Program" (in German: "Gebäudeprogramm")), which provides subsidies for energy efficiency and renewable energy solutions in buildings [6,49]. The cantons support carbon emissions reduction by providing additional funds to increase the level of subsidies or support solutions not included in the scope of Programme Bâtiments [51]. By 2017 carbon emissions from buildings had been reduced by only $23 \%$ (or 3.91 million $\mathrm{t} \mathrm{CO}_{2}$ ) compared to the 1990 level [52]. Another $27 \%$ (or 2.93 million $\mathrm{t} \mathrm{CO}_{2}$ ) should be saved by the year 2030, which is hardly reachable in view of the current trends $[6,49,50,52]$. Despite climate policy efforts, the majority of heat demand is still covered by fossil fuels (Figure 1). By the year 2017, buildings caused about $27 \%$ of all carbon emissions in the country (13 million $\mathrm{t} \mathrm{CO}_{2}$ per year) [52].



Figure 1. Space heat demand of Swiss households by energy source, weather-adjusted [53]. Reproduced from [Der Energieverbrauch der Privaten Haushalte 2000-2016], BFE: 2017.

In 2013, Geneva's public utility Services Industriels de Genève (SIG) launched the renewable heating program Chaleur renouvelable to achieve additional carbon savings in the canton [54]. The program is focused on replacing fossil fuel and direct electric heating systems by the following renewable heating systems: heat pumps (main focus), solar thermal and wood-based systems. We consider heat pumps to be among renewable heating technologies, according to the EU Directive on the promotion of the use of energy from renewable sources (2009/28/EC, RES Directive, § 2), as it recognizes heat pumps as using renewable energy sources from air, water and ground [55].

In 2013-2016, the program was complementary to Programme Bâtiment and cantonal programs as the latter have strict technical eligibility requirements that in practice lead to subsidies being available for new construction only (since 2017, Chaleur renouvelable is merged with Programme Bâtiment). Chaleur renouvelable provided subsidies covering on average about $10 \%$ of initial investment (i.e., equipment and installation costs), depending on the amount of $\mathrm{CO}_{2}$ or electricity savings achieved. Chaleur renouvelable also developed a long-term relationship between the program and installers (i.e., companies that provided installation and maintenance services), with an aim to encourage renewable solutions and to increase the quality of heating services. Installers wishing to become partners of the program have to be accredited by the program operator by satisfying requirements on the quality of provided services and employment conditions. A list of accredited installers was made available on the program website and all program communications. Partnering installers received financial incentives of CHF 250 (about EUR 220) for every renewable 
system installed, as well as training support and assistance in finding customers (i.e., through telemarketing and mailing activities organized by the program operator) [56]. The quality of services provided by installers was also checked by site visits to some of the houses. By 2017, over one hundred and fifty renewable heating systems had been installed, mainly in single-family houses (Figure 2). We chose to study the example of Chaleur renouvelable in 2013-2016 due to its focus on existing building stock, proximity to homeowners and close collaboration with installers.

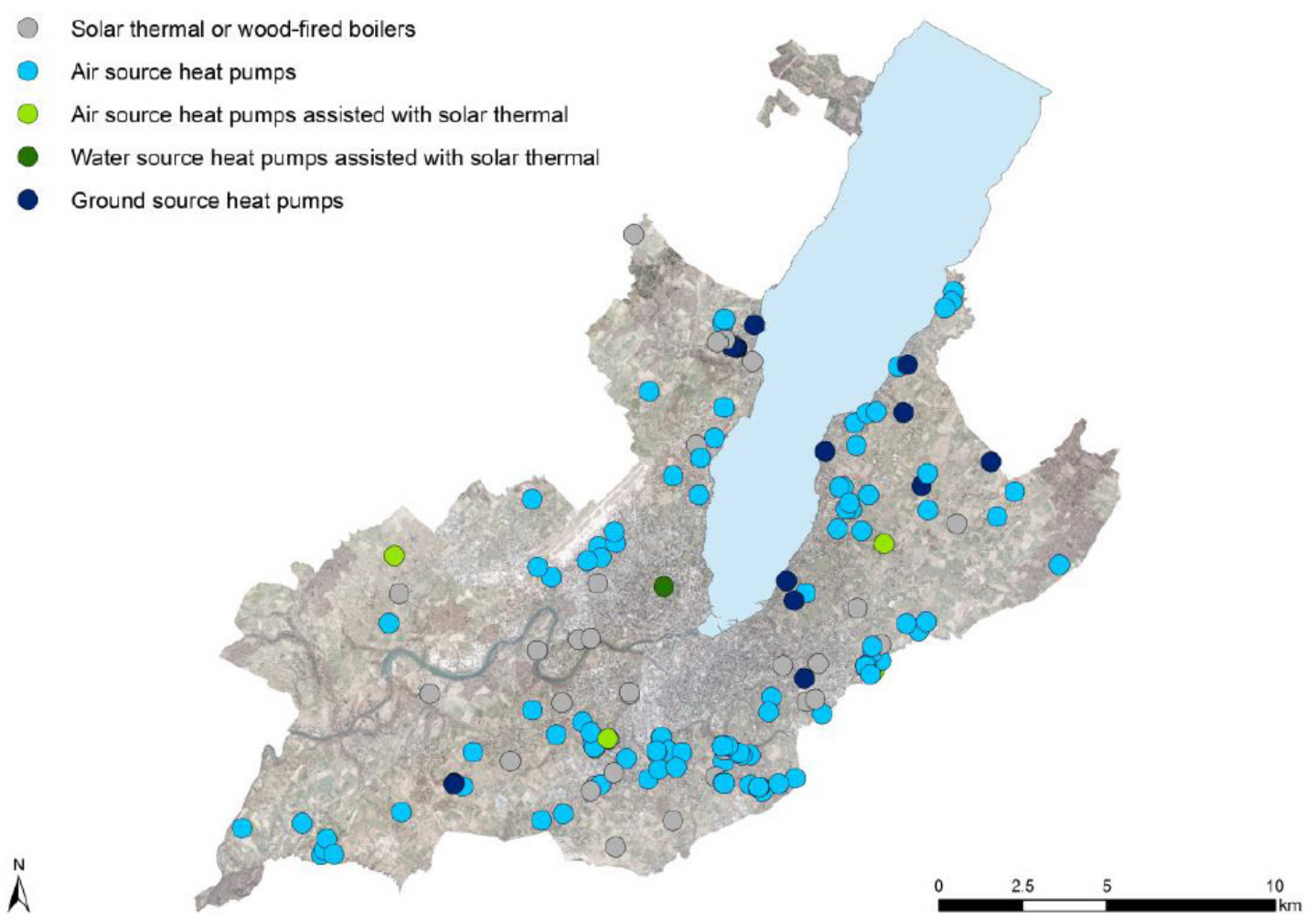

Figure 2. Renewable heating systems installed with support of Chaleur Renouvelable program in 2013-2016.

\subsection{Method}

The majority of homeowner studies use survey data on stated preferences regarding hypothetical decisions $[24,27,57]$. Less research is based on real homeowner choices coming from Census data [12], homeowner surveys $[18,23]$ or interviews $[26,39]$. There is a clear preference to perform quantitative studies with large population samples $[9,15-18,22]$. Quantitative approaches allow to evaluate the scale of different phenomena by use of discrete choice models $[25,29]$ and other statistical analyses $[15,17,29]$. The qualitative research base is less developed $[19,20,58]$. This can be explained by the fact that qualitative studies focus on small population samples and do not allow conclusions to be drawn for the population in general [59]. Still, qualitative studies have advantages. In-depth interviews allow the study of phenomena in greater detail, obtain a deeper understanding and even find out elements not taken into account in the study preparation stage $[11,46,58]$. Qualitative studies can hence help to develop quantitative studies of higher quality [60].

Having the objective to better understand homeowner practices and experiences (Section 1) [60] and taking into account the small scale of the Chaleur renouvelable program (Section 3.1), we chose to conduct qualitative interviews for our study instead of a quantitative approach. The program operator (SIG) sent letters to all single-family house owners who had installed heat pumps and received incentives from the Chaleur renouvelable program in 2013-2016 (Figure 2), proposing to take part in the study for a remuneration of CHF 50 (approximately 44 euros) [56]. Then the survey company DemoSCOPE contacted the households by phone to propose and arrange face-to-face interviews [61]. Households 
could express their interest in taking part in the interview by e-mail or by phone. When choosing the participants, maximum variability with regard to installers engaged was aimed for. Fifteen interviews were performed by DemoSCOPE, lasting 25-45 min each. A semi-structured interview form with open-ended questions was used (Appendix A). The interview guide, reported in Appendix A, was divided into the following four sections: heating system and installer, Chaleur renouvelable program, other energy measures implemented, and consumption behavior, as well as socio-economic data. The scope of the interview was wider compared this study (compare research questions in Section 1), in order to obtain a clearer understanding of the situation and compare it to the findings from the literature (Section 2). Participants were also allowed to add information they found relevant even if it was beyond the scope of the proposed questions. DemoSCOPE recorded the replies via audio recording, made transcripts and transmitted them to the University of Geneva for thematic analysis [11]. The analysis of the transcripts was conducted by the University of Geneva and DemoSCOPE. The focus was on identification of themes appearing in the interview transcripts, and not on individual characteristics or quantitative aspects. The themes were classified and grouped into sections with respect to the aims of the study (Section 1). The obtained results gave insights into homeowners' practices and attitudes regarding the choice of the heating systems and of installers (Section 4.2), experiences with installation and use of the heat pumps in daily life (Section 4.3), and feedback on participation in the renewable heat program (Section 4.4). Additional themes were identified, including homeowners' practices related to the implementation of energy efficiency measures, attitudes and practices regarding green energy tariffs and energy consumption monitoring (Section 4.5). The research was conducted on an anonymous basis and with the interviewees' consent, respecting the ethical norms of research in social sciences [62]. We compared our findings with the results of a marketing study (unpublished) performed by SIG before the launch of Chaleur renouvelable program. This study had been conducted with a selected panel of homeowners in Geneva who expressed their preferences with regard to a hypothetical situation of changing the heating system and receiving subsidies. In addition, we presented the summary of results to installers (partners of the program) in order to receive their feedback.

\section{Results}

\subsection{Participant Profiles}

As detailed in Table 1 and Appendix B, the majority of the interviewees were elderly people, and had a profession or interest related to technology or the environment. The years of installation covered the full operational period of Chaleur renouvelable (2013-2016).

Table 1. Participant profiles.

\begin{tabular}{|c|c|}
\hline Parameter & Values \\
\hline Heat pumps installed & Air source (12), Ground source (3) \\
\hline Year of installation & 2008 (1), 2013 (2), 2014 (7), 2015 (3), 2016 (2) \\
\hline Installers & Partners (6), previously excluded from partnership (1), non-partners (3) \\
\hline Heating agent before & Heating oil (7), electricity (5), natural gas (2), new construction (1) \\
\hline Building construction period & 1950s (1), 1960s (3), 1970s (2), 1980s (6), 1990s (2), 2000s (1) \\
\hline Size of the households & 1 person (5), 2 persons (5), 3 persons (3), 4 persons (1), 5 persons $(1)$ \\
\hline Age of household members & 0-18 years old (3), 19-30 years old (5), 31-45 years old (2), 46-65 years old (9), 66 + years old (14) \\
\hline Professional situation & Retired (17), employed (8), entrepreneur (2), house wife/husband (1), students living with parents (5) \\
\hline Professional fields & $\begin{array}{c}\text { Engineering and related occupations (5), education (3), secretariat (3), housekeeping (3), informatics (2), } \\
\text { insurance (2), humanitarian services (1), social work (1), public relations (1), banking (1), law (1), science (1), } \\
\text { other occupation (3), not specified (1), students (5) }\end{array}$ \\
\hline
\end{tabular}

Fourteen heat pumps were installed in existing houses, and one heat pump was installed in a newly constructed house. The latter household did not receive any subsidy 
from Chaleur renouvelable, but requested participation in the study. This household had made a positive experience with their heat pump and encouraged their family members to install one in their existing houses, and to request the subsidy. We decided to include this case in the study. The heat pumps were installed by ten installers, six of whom were program partners, three were non-partners, and one was previously excluded from the partnership, due to low quality of the provided services.

\subsection{Choice of Heating System Type and Installer}

Among the reasons for households to change their heating system was the technical necessity. Either the previous system had broken down or was at risk to do so, or it no longer corresponded to the legal requirements, and its renovation was either too costly or technically not possible. Some households decided to change their heating system before the expected changes in legislation took place. Others decided to change the heating system voluntary, for either environmental (i.e., less pollution), economic (i.e., lower energy bills) or comfort reasons (i.e., increased indoor temperature, improved air quality, space gains, higher autonomy of energy supply compared to heating oil boiler). One household was convinced by an installer who had a pro-active approach. The reasons to change the heating system are summarized in Table 2.

Table 2. Reasons to change the heating system. Numbers in brackets (also for other quotes) refer to interviewee numbers given in Appendix A.

\begin{tabular}{|c|c|c|}
\hline Category & Reason & Quotes \\
\hline Necessity & The old boiler had to be replaced & $\begin{array}{c}\text { "My heating system broke down, I couldn't fix it anymore. I couldn't do anything else. } \\
\text { I didn't have a choice." (6) } \\
\text { "I had to do a check of the (heating oil) tank and it turned out that it would have cost } \\
\text { me a lot to make it compliant with the new standards. A double-walled tank would } \\
\text { have been necessary. The boiler had to be changed, too. I knew that a lot of work would } \\
\text { be required to bring my heating system up to (the new) standards." (5) } \\
\text { "The change in law that bans heating with electricity (direct electric heating) pushed } \\
\text { me to change." (1) }\end{array}$ \\
\hline $\begin{array}{l}\text { Voluntary } \\
\text { choice }\end{array}$ & $\begin{array}{l}\text { Economic reasons } \\
\text { Comfort } \\
\text { Environmental intentions }\end{array}$ & $\begin{array}{c}\text { "My husband liked it and he thought it was more ecological." (11) } \\
\text { "My former heating system was too energy-consuming, and it did not correspond } \\
\text { anymore with my principles." (10) }\end{array}$ \\
\hline Other & $\begin{array}{l}\text { New construction } \\
\text { Convinced by the installer }\end{array}$ & $\begin{array}{l}\text { "Firstly, we were contacted by people from Meyrin (installers from Meyrin } \\
\text { municipality in Geneva) who then came to explain us the system." (11) }\end{array}$ \\
\hline
\end{tabular}

Some households opted for a heat pump from the very beginning, without considering the technological alternatives. These households were already familiar with heat pump technology, for professional reasons or personal interest. Some households estimated the economic viability of heat pumps for their houses themselves. Other households studied the different types of heating systems available (including renewable and fossil-based ones).

The following information sources were used by the households when choosing a heating system type: social circles (i.e., friends, neighbors, and family), the Chaleur renouvelable program (i.e., SIG website, mailing, and phone call), installers and other contractors (including already-known and new contacts), media (i.e., internet, including discussion forums, printed journals), as well as special events (e.g., conferences).

A summary of the household practices that are applied when choosing a heating system type is given in Table 3 . 
Table 3. How heating system type was chosen.

\begin{tabular}{|c|c|c|}
\hline Category & Options & Quotes \\
\hline \multirow[t]{2}{*}{ Heating system type chosen } & From the beginning & $\begin{array}{c}\text { "I know about the heat pump technology since 1946, so there is } \\
\text { enough experience by now. From my perspective, it should } \\
\text { nowadays be the standard." (3) }\end{array}$ \\
\hline & $\begin{array}{l}\text { After consideration of different } \\
\text { technological options }\end{array}$ & "I chose the heat pump by exclusion." (5) \\
\hline \multirow{3}{*}{$\begin{array}{l}\text { Information sources used to } \\
\text { choose a heating system type }\end{array}$} & $\begin{array}{l}\text { Social circles } \\
\text { Utility renewable heating program }\end{array}$ & $\begin{array}{c}\text { "We asked our friends and neighbours, because many of them in } \\
\text { our road installed heat pumps. We also looked at the website of } \\
\text { SIG (utility operating Chaleur renouvelable program) that } \\
\text { provides a lot of information." (1) }\end{array}$ \\
\hline & $\begin{array}{l}\text { Media sources } \\
\text { Installers }\end{array}$ & "We received a letter from SIG regarding renewable energies." (13) \\
\hline & $\begin{array}{l}\text { Own expertise } \\
\text { Thematic events }\end{array}$ & $\begin{array}{c}\text { "I also looked for the information on the internet. There is a lot of } \\
\text { information." (5) }\end{array}$ \\
\hline
\end{tabular}

Among the reasons mentioned for choosing a heat pump (Table 4) were advice and experience from social circles; advice by installers or other contractors; advertisement (in printed journals of SIG and other organizations); economic reasons (in view of an expected increase in fossil energy prices); environmental considerations; financial incentives offered; and comfort (more floor space available). Some households chose heat pumps by excluding other heating system types. In this context, fuel oil systems were associated with pollution, extra space needed for the tank, and the need to refill the tank. Natural gas systems were not chosen, due to absence of the distribution grid, negative experience by a member of social circles, a fear of accident, or unwillingness to choose this solution for other unknown reasons ("did not want to"). One household preferred to install a groundsource heat pump compared to an air-source heat pump, to avoid additional noise. In contrast, another household chose an air-source heat pump instead of a ground-source heat pump, for reasons of technical feasibility and soil protection. One household chose a heat pump as its member was professionally related to heat pump technology (i.e., installer and member of heat pump association). Some households mentioned that they did not have much time to make their decision. The previous heating system was broken or malfunctioning, and they had to quickly install another one. The households also mentioned that they faced difficulties in evaluating the options and making calculations "whether it is worth investing".

Table 4. Why heat pump was chosen.

\begin{tabular}{|c|}
\hline Category \\
\hline
\end{tabular}

Advice and experience of friends, neighbors, family members Advice of installer or another contractor

Factors influencing choice of heating system type

Advertisement by utility and from other sources

Economic and/or environmental reasoning Interest and expertise in technology

Subsidies

By exclusion

Comfort

Decision-making constraints

Limited time for installation

Difficulty in making economic evaluation

When choosing an installer, the households used a variety of information sources, including the list of partners of the Chaleur renouvelable program (found on the SIG website, mailing, printed journals), social circles, websites, and advertisement by installers. The information campaigns that were organized by the program operator were found to have a long-term, rather than an immediate, impact. For example, when households decided 
to change the heating system, they remembered facts or were able to find information on the program months or sometimes even years after having received the mailing from Chaleur renouvelable.

The households often made a choice among several installers. The contact was usually initiated by households, less frequently by installers. In some cases, the households considered only one installer from the beginning; they either preferred the same installer they had worked with earlier on, or they were advised to choose a specific one (for example, by their former installer who was specialized only on fossil-based systems, or by the contractor who was involved in the construction of the building). The installers visited the houses and made offers afterwards. In some cases, installers arranged a visit to already-installed heat pumps in other houses (e.g., at neighbors).

The households mentioned the following preferences they had in choosing their installers: the company was a partner of the Chaleur renouvelable program (i.e., approved by SIG as a neutral and trustable party), the installer was advised by a member of social circles or was known before; the installer made an offer free of charge, or its offer was the least expensive; the company provided all installation services itself (without subcontracting), was situated in proximity to the house, or had a good commercial approach (i.e., "convincing", "personalized", "local craftsmanship", "reliable"). One household chose the contractor based on the model of the heat pump that was proposed. Not all households chose installers who were partners of the Chaleur renouvelable program, but they were still able to receive the subsidy, based on examination of their request by the program operator.

The outline on homeowner practices in choosing installers is given in Table 5.

Table 5. How installer was chosen.

\begin{tabular}{|c|c|c|}
\hline Category & Options & Quotes \\
\hline \multirow{3}{*}{$\begin{array}{l}\text { Information sources to } \\
\text { choose installer }\end{array}$} & $\begin{array}{l}\text { Renewable heating program run by } \\
\text { utility }->\text { list of partners }\end{array}$ & $\begin{array}{l}\text { "We received a letter from SIG regarding renewable energies. There } \\
\text { was a list of installers they recommended." (13) }\end{array}$ \\
\hline & $\begin{array}{c}\text { Advice by a member of social circles, } \\
\text { constructor or known installer } \\
\text { Website and flyers provided by } \\
\text { installer }\end{array}$ & \multirow{2}{*}{$\begin{array}{c}\text { "One friend made excellent experience with an installer, and I } \\
\text { received a letter from SIG. I called them (SIG) to know whether the } \\
\text { company (the installer) was approved (was a partner of Chaleur } \\
\text { renouvelable program). I didn't search anywhere else." (7) } \\
\text { "It's simple, it's him who contacted me... He called me on the } \\
\text { phone." (4) }\end{array}$} \\
\hline & Contacted by installer (by phone) & \\
\hline
\end{tabular}

Homeowners contact $1->\mathrm{n}$ installer(s)

Installer(s) come(s) to the house

Steps in choosing the Homeowners receive offer(s) from installer installer(s)

Homeowners visit other houses to see heating systems implemented by installer

Partner of renewable heating program

Advice by a member of social circles

Least expensive offer

Factors influencing the choice of installer
One company doing all jobs

Free offer

Proximity

Installer known already before

Perceived qualities of installer

(convincing, craftmanship)

Heat pump model proposed
"Thanks to a friend. The installer works still in a workshop and he is very committed. These are professionals who know what they do. I trusted as he was the best." (7)

"The name was cited by SIG. I went there ... (to the installer) and discussed with the head ... We quickly started a technical discussion and I appreciated our exchange." (3)

"We called three installers and chose the most advantageous offer after having consulted a member of our family." (8)

"We contacted three companies from the list to find out whether they would be ready to make us an offer. We wanted to have one company taking care of everything. We didn't want to fall between two chairs with two companies. In case we would have a problem, we didn't want them to send us from one to another." (1)

"We chose those who were the closest (geographically) to us." (13) "I contacted the installers and had a look at heating systems previously installed by the installers in other houses. The owner of the system told me that he was generally satisfied. It was a neighbour." (5) 


\subsection{Feedback on Heat Pump Installation and Use}

We asked households if they were satisfied with the services that were provided by the installers, during both the installation and the post-installation period. Households who were satisfied with the installation services described installers as reliable and competent. However, in some cases, the satisfied households perceived installers as lacking knowledge about installation and setting procedures. This can be related to the fact that some installers consulted the manual and learned how to install a heat pump on the site. This feedback does not necessarily imply that the installers are incompetent. According to the comments received from the installers, their doubts on how to install were mainly related to the continual launch of new models of heat pumps, each having peculiarities with regard to their installation and setting. The households who were dissatisfied with the installation services described installers as having no knowledge or confidence in the technology, including installation and setting. These households mentioned that installers had to consult the manual, and they also reported that some installers had to call the equipment producer. In one case, even the equipment producer could not provide some answers about how to adjust the system.

The households paid high attention to the quality of the explanations provided by the installer during the installation process. The satisfied households considered the information they received as sufficient. In these cases, the installer took the time to explain, and encouraged households to actively follow the heat pump installation and setting procedures. Some households also positively referred to complementary information that was provided by the program operator during the site visits at their homes. The dissatisfied households answered that they received no explanation from the installer (i.e., including on setting), and that they still had some unresolved questions about their heat pumps. The quality of the explanation given by the installer resulted in some households feeling completely at ease with the use of their heat pumps ("excellent setting", "not much to do"), while other households felt uncomfortable and lost ("some questions stay unresolved", "installer cannot answer the questions", "manual difficult to understand").

During the post-installation period, the households had questions regarding the use of heat pumps, in particular the setting. They addressed these questions to the installers, equipment producers, and Chaleur renouvelable program operator, as well as searched for information on the internet. In most cases, homeowners had a positive attitude towards the after-sale services provided by the installers, although there were also some cases when installers were unreachable, or refused to provide any service (i.e., the household was proposed another company for maintenance and was worried about losing the guarantee on the equipment).

Overall, the households expressed general satisfaction with the services provided by eight installers, including both program partners and non-partners. Two installers provided unsatisfactory services, including one non-partner and one company that was previously excluded from the partnership. We investigated, in more detail, the cases when homeowners were dissatisfied with the services provided by installers. In one case (installer previously excluded from the partnership program), the complaints were clearly related to the bad quality of the heat pump installation and setting. The program operator had to intervene in order to have the problems fixed by another installer. In another case, a member of the household complained that no after-sale services were provided by the installer (non-partner). In fact, that household member had a technical professional background and wanted to have full control of the system, allowing them to further the functions that are foreseen by the standard settings. The installer refused to give this access, as it could possibly lead to the heat pump malfunctioning and would not ensure guarantee on the equipment. We considered this case as atypical and related to communication (diplomacy of installer when rejecting client's request) rather than to an actual problem of after-sale services. This example shows that homeowner studies should not be limited to feedback from one side (i.e., the household) without considering the other (i.e., installer). 
We also asked the households if they had evaluated the change in their heating costs after heat pump installation. Some households mentioned that they analyzed their energy bills. Others did not perform any evaluation. This group included both households who were sure about having reduced their costs ("didn't check, but sure to have made savings") and those who did not know if any savings were realized (due to technical complexity in view of the presence of another heating system, or due to the fact that the heating system was replaced recently). The most positive feedback was given by households who previously had a direct electric heating system. They claimed that the expected energy savings were fully realized ("the given guarantees are overfulfilled"). However, there were also households who continued to have large electricity bills, did not perceive any savings, and were dissatisfied. In was more difficult to evaluate the change in heating costs for households who previously had a fossil-based heating system. This may be related to the fact that it is easier to evaluate the change in electricity bill when making the transition from an electric boiler to a heat pump. In the case of fuel oil or natural gas systems being replaced, additional efforts (i.e., due to different energy bills) and time (i.e., due to different billing periods) are required to evaluate the change in energy demand and respective costs.

We also asked households if they were satisfied with their heat pump. For the majority of the households, this was the case. One household hesitated as it was not able to perform an economic evaluation of its investment decision ("need to calculate whether it is really financially interesting"). The satisfied households appreciated the heat pump technology mainly for comfort reasons ("very easy setting", "allows to save space", "no fire or smoke", "no need for chimney sweeping"), and also for environmental reasons ("more ecological"). They were also influenced by the experience made with installers ("competent installer", "good explanation", "quality of after-sale services", "speed of installation"). The satisfied households were recommended to install a heat pump within their social circles, and even invited people to their house to show the system. Households who were dissatisfied with their heat pumps referred to technical reasons caused by bad quality of installation ("higher energy consumption than expected", "bad setting", "noise", "cold indoor temperature", "leakages", "not enough hot water", "air in the radiators"). There were also complaints with regard to the peculiarities of heat pump technology and models ("before we had a defrost mode for the time of vacations, now we can only reduce the temperature and it takes too long time to reheat", "difficulties with day/night electric panel", "would prefer a smaller model"). The problems with installers and legal procedures also contributed to household dissatisfaction with their choice of a heat pump ("incompetent installer", "no/bad quality of after-sale services", "installation took a lot of time", "had to ask for authorization to drill boreholes", "state refused to include the cost of a heat pump in value of the house" (this refers to the case of a single-family house situated in a densification zone, where the state has the right to expropriate the house, with compensation of real estate value, in order to construct multifamily houses). The dissatisfied households discouraged members of their social circles to install heat pumps.

Table 6 provides a summary of homeowner feedback on installers and heating systems, and the respective implications within social circles.

\subsection{Participation in Renewable Heating Program}

The households learned about the Chaleur renouvelable program through a variety of information sources, as follow: SIG (mailing, printed journal, web site), installers, media (internet, printed journals), as well as social circles. Some households were aware, in advance, that subsidies existed. Installers used subsidies as a "sales argument". In some cases, the heating systems had to be urgently replaced (see Section 4.2), so the question of subsidies came after the decision to install a heat pump was taken, or even after the installation started. 
Table 6. Feedback from homeowners.

\begin{tabular}{|c|c|c|}
\hline \multicolumn{3}{|c|}{ Satisfied Homeowners } \\
\hline Feedback on & Opinions & Quotes \\
\hline Installers & $\begin{array}{l}\text { Competent installer, good explanations, high } \\
\text { quality of after-sale services, speed of installation. }\end{array}$ & $\begin{array}{c}\text { "I am very satisfied. I liked everything. If I have a problem, } \\
\text { I call my installer. He explains everything to me by phone. } \\
\text { Everything is simple." (2) } \\
\text { "They (installers) are serious about their work and they are } \\
\text { competent." (7) }\end{array}$ \\
\hline Heat pumps & $\begin{array}{l}\text { Easy setting, saves space, more environmentally } \\
\text { friendly, absence of fire and smoke. }\end{array}$ & $\begin{array}{c}\text { "It is very simple. It requires to turn one button in autumn } \\
\text { and turn one button in the spring. Apart from that, I do not } \\
\text { have to take care of it." (3) } \\
\text { "The setting is easy, and my installer is always available to } \\
\text { answer (the questions). SIG provided complementary } \\
\text { information when they came to check the system." (10) }\end{array}$ \\
\hline Implications & $\begin{array}{l}\text { Homeowners with a positive experience advise } \\
\text { (and show) heat pumps to their friends, neighbors } \\
\text { and family members. }\end{array}$ & "My costs (heating costs) decreased by two-thirds." (10) \\
\hline
\end{tabular}

Dissatisfied Homeowners

\begin{tabular}{|c|c|c|}
\hline Feedback on & Opinions & Quotes \\
\hline Installers & $\begin{array}{l}\text { Incompetent installer, poorly regulated heat pump, } \\
\text { after-sale services of bad quality or absent, } \\
\text { authorization for boreholes required, long } \\
\text { duration of installation, installation mistakes }\end{array}$ & $\begin{array}{c}\text { "The installer is remarkably incompetent, because he is not } \\
\text { capable to adjust the system. He told me he should take a } \\
\text { course but did not do it. He cannot help me at all. I called } \\
\text { him at least } 50 \text { times, but he does not do anything." (5) } \\
\text { "It is a prerequisite that the installers... know what they } \\
\text { are doing." (1) }\end{array}$ \\
\hline Heat pumps & $\begin{array}{l}\text { Higher energy consumption than expected, noise, } \\
\text { frost, air in radiators, shortage of sanitary hot } \\
\text { water, would prefer a smaller model. }\end{array}$ & $\begin{array}{c}\text { "The installer had some ideas, but not very clear. We had to } \\
\text { call the manufacturer of the heat pump. Even the } \\
\text { manufacturer was not aware of the latest details of the } \\
\text { configuration panel. We had to look up the manual to } \\
\text { understand." (1) }\end{array}$ \\
\hline Implications & $\begin{array}{l}\text { Homeowners with the negative experience advise } \\
\text { against heat pumps to their friends, neighbors and } \\
\text { family members. }\end{array}$ & "I think that the energy consumption could be lower." (9) \\
\hline
\end{tabular}

In many cases, the entire administrative procedure (application for the subsidy) was taken care of by the installer. This was highly appreciated by the households ("it is very reassuring to have an installer who does everything"). Some households did not check any details about the Chaleur renouvelable program, while others read information provided by the program operators (via web site, printed journal). Those households who chose a non-partner installer had to implement the entire administrative procedure themselves. They found that information on the program's web site was clear and that the procedures were easy to follow.

Among the support provided by the Chaleur renouvelable program, the list of partner installers was most appreciated. This may be explained by the concern of households to choose a competent installer, especially given the high initial investment costs of a heat pump compared to conventional heating technologies. They, therefore, appreciate receiving advice from a third party that is neutral and trustable (i.e., by SIG being a public utility and operating the renewable heating energy program). An explanation as to why the economic support was not appreciated to the same extent could be the low level of subsidies (about $10 \%$ of initial investment costs). The majority of households acknowledged that they would have installed a heat pump anyway, even without receiving a subsidy. The subsidy was received positively ("allows to reduce the costs", "the fact that it is the State who gives money"), but was seen as a "good opportunity" or "confirmation signal" about the technology choice rather than as meaningful economic driver. In most cases, the 
initial investment costs were covered by personal savings, only a few households took a mortgage. If assessed very strictly, Chaleur renouvelable can hence be considered to have a free-ridership effect close to $100 \%$. This is in accordance with a marketing study that was performed by SIG before the launch of the program, showing that subsidies should cover at least $20 \%$ of the initial investment costs to actually influence household decisions. However, indirect impacts of the program should also be taken into account, e.g., through training activities for installers, information support (i.e., list of partners), and information campaigns for the households (which received more attention if accompanied by a subsidy). It is difficult to evaluate these indirect impacts, but they surely should be accounted for, given the influence of information and technology reputation on homeowner decisions (Sections 2 and 4.2).

The feedback received from homeowners points to the importance of flexibility in the administrative procedures of renewable heat programs, including the choice of installers and timing for applications (possibility to request a subsidy after the heating system had been replaced).

Homeowner feedback on participation in the Chaleur renouvelable program is summarized in Table 7 .

Table 7. Homeowner feedback about participation in renewable heating program.

\begin{tabular}{|c|c|c|}
\hline Category & Options & Quotes \\
\hline \multirow{5}{*}{$\begin{array}{l}\text { Information sources } \\
\text { about the program }\end{array}$} & $\begin{array}{l}\text { Utility-operated renewable } \\
\text { heating program }\end{array}$ & $\begin{array}{l}\text { "One year before the problem with my heating system I got a letter from SIG, but I } \\
\text { didn't consider it. When the problem with the heating system occurred it made me } \\
\text { change my mind. I found the relevant information as I have filed everything." (6) }\end{array}$ \\
\hline & Installer & $\begin{array}{c}\text { "The information given by my installer was good and it was confirmed and } \\
\text { complemented by SIG." (10) }\end{array}$ \\
\hline & Media & "The journal "Mieux Vivre" ("Live better" by SIG) triggered me to take action. I saw \\
\hline & Neighbors & $\begin{array}{l}\text { that SIG proposed help, and I contacted them to obtain a list of the approved installers. } \\
\text { But then it was the installer who took the next steps." (3) }\end{array}$ \\
\hline & $\begin{array}{l}\text { Awareness about existence of } \\
\text { subsidies/program }\end{array}$ & $\begin{array}{c}\text { "I knew that the subsidy existed. I had read this in the newspaper. The installers heavily } \\
\text { insisted on this point (the subsidies). It was a sales argument." (4) }\end{array}$ \\
\hline \multirow[t]{2}{*}{ Participation process } & $\begin{array}{l}\text { Subsidy request was made by } \\
\text { installer or homeowner }\end{array}$ & $\begin{array}{l}\text { "I received the letter from SIG with the information. I knew that the installer was not in } \\
\text { the list of the approved companies (partners), but I had much confidence (in that } \\
\text { installer). So, I contacted the program manager to explain that I wanted to choose that } \\
\text { installer. The program manager told me he would study the case and his decision was } \\
\text { positive. It was important for me to work with the installer I trust." (7) } \\
\text { "We don't remember much as it was the installer who told us what to do. He told us } \\
\text { what steps to take. It was reassuring for us to have an installer who guided us. It is good } \\
\text { to know he is available in case we need him." (8) }\end{array}$ \\
\hline & $\begin{array}{l}\text { Many heating systems are } \\
\text { installed in a hurry (e.g., following } \\
\text { breakdown of old system), } \\
\text { subsidy requested afterwards }\end{array}$ & $\begin{array}{c}\text { "I had to have the system installed in a hurry, as my heating did not work anymore. } \\
\text { Then I found out about the program of SIG. I called (the program manager) who told me } \\
\text { once the system is already installed SIG doesn't give subsidies, but he would see if he } \\
\text { could do anything for me. It was the first time someone asked for this, so I really } \\
\text { appreciated the positive reaction of the program manager." (6) } \\
\text { "It was the installer who told me that I was entitled to receive subsidies. It was him who } \\
\text { took all the steps. They did everything (installer)." (13) }\end{array}$ \\
\hline \multirow{3}{*}{$\begin{array}{l}\text { Perceived advantages of } \\
\text { renewable heating } \\
\text { programs }\end{array}$} & List of installers most appreciated & $\begin{array}{l}\text { "The choice was made from the list proposed by SIG." (10) } \\
\text { "One never receives information on heat pumps. For example, I was surprised to learn } \\
\text { that the installer cannot offer after-sale services. I would have preferred to know it in } \\
\text { advance, even by a neutral organization like SIG." (4) }\end{array}$ \\
\hline & & $\begin{array}{c}\text { "For me it was a necessity. The subsidy is ridiculous compared to the cost (total cost of } \\
\text { installation). I didn't have a choice. I had to change my heating system." (6) }\end{array}$ \\
\hline & $\begin{array}{l}\text { Subsidy is appreciated, but has } \\
\text { low impact on decision to install a } \\
\text { heat pump }\end{array}$ & $\begin{array}{l}\text { "It was the subsidy that I was interested in, but it was reassuring to have an installer } \\
\text { who had been approved. For the installer this is a sales argument". (5) } \\
\text { "The point of departure was the end of life of my installation (heating system). We had } \\
\text { to change our installation and I wanted to have the latest technology. The subsidy did } \\
\text { not play a role at the beginning, but it helps, it is always positive." (3) }\end{array}$ \\
\hline
\end{tabular}

\subsection{Additional Information}

We asked a number of additional questions to the households, with regard to their energy-related decisions. We learned that a number of households implemented other types of energy measures, including changing windows and insulating the building envelope. 
These measures were implemented either before or after installation of the heat pump. There was a variety of reasons for households to implement energy measures, including legal obligations and environmental considerations. The household did not always request a subsidy, even though some of them knew that subsidies were available for the type of energy measures implemented (others did not know that subsidies existed).

In general, the households did not have any concrete plans to implement further energy measures in the future ("we didn't think about it", "we already did enough"). A number of households expressed interest in installing solar PV panels ("to supply of the heat pump by consuming locally generated renewable electricity"). Among the reasons provided for not implementing energy measures was the age of the household members (i.e., a lot of them were retired), and uncertainty whether their children would live in the house. Some houses were also situated in densification zones and could be destroyed in the future.

The households acted differently with regard to energy consumption monitoring. Some of them followed their consumption regularly and were interested in achieving energy savings ("compare the consumption with previous periods", "to see if the heating system functions well and adapt it, if needed"). Other households checked the metered data, but did not have particular interest in them (this group also includes households who claimed to have ecological intentions, but revealed no interest in monitoring their energy consumption data.). Finally, there were some households who did not pay any attention to their energy bills. An opportunity to consult energy consumption data online was highly appreciated. Among the identified barriers for energy consumption monitoring was the perception of not being able to make any difference ("anyway, we can't change anything"), and that the energy bill system was not adapted (i.e., homeowners paid according to consumption predictions, which were corrected later, and it was only possible to compare from one year to another).

Currently, SIG offers different types of electricity tariffs depending on the share of renewable energy (up to 100\%) and its origin (up to 100\% generated locally, in Geneva) [63]. The households revealed different attitudes to "green tariff" plans. Some preferred to have a balance between environmental contribution and price ("compromise between the economy and the preservation of the planet", "I can think about ecology as I have financial means, otherwise I would have chosen economy"), others saw local business opportunities, which were sometimes also motivated by environmental benefits ("to promote the local energy in Geneva"), while again others made their decisions purely based on price considerations ("in Switzerland the energy is already clean"). There were also households who were against "green tariffs" ("I prefer subsidies because they encourage people to change their behaviour... taxing people is unfair"). In addition, most households did not know which type of tariff they had subscribed to. We found all types of electricity tariffs among the studied households, e.g., with no clear preference for "greener" tariffs by households who installed heat pumps.

\section{Discussion}

\subsection{Which Information Sources Do Homeowners Use When Choosing an Installer?}

The present study addressed the current knowledge gap on homeowners' behavior regarding to the choice of installers (Section 2.2). The findings from the interviews (Sections 4.1 and 4.2) show that homeowners often choose installers after having decided to replace the heating system (replacement mostly by necessity, but sometimes other reasons). Homeowners tend to prefer internal sources of information for choosing installers. They consult members of their social circles (neighbors, family, and friends), as well as field professionals (already-known installers, constructors, utility). Many homeowners appreciate and use the advice provided by the renewable heating program, regarding the choice of installers (list of partner installers), as they perceive the program operator as a neutral and trustable party (Section 4.4). Homeowners also use external information sources, including installer websites and flyers. 
There are also cases when homeowners choose installers who take an initiative to propose their services (via advertisement campaigns). Information campaigns can have mid- to long-term effects, when homeowners receive information, but use it months or years after, when they decide to replace their heating system (Section 4.2).

\subsection{Which Factors Impact the Choice of Installers?}

To our knowledge, despite the significance of the topic, only a few studies have analyzed the following selection criteria that are applied by homeowners when choosing heating system installers: provided services $[9,17,31]$ and proximity [28]. The results of the interviews allow us to get a deeper understanding on how homeowners make their choice (Section 4.2). In some cases, homeowners directly choose the installer; they either follow the advice of a member of a social circle, or prefer to keep the same installer, or have no possibility to choose (the latter is more likely in the case of new construction than renovation). Many households make a selection among several installers, based on a variety of criteria, going beyond the provided services, proximity and cost criteria. The general trust in the installer is an important factor, which can be influenced by external factors (e.g., advice of a member of social circles, recommendations by the renewable heat program) and internal factors (e.g., installer's sales approach, communication skills). The fact of providing an offer free of charge and a possibility to visit already-installed heating systems (for example, at neighbors' houses) has a positive impact on the homeowner's decision. Homeowners also prefer installers who take care of the entire installation process, rather than having to deal with several companies.

\subsection{How Do Interactions with Installers Impact Homeowner Satisfaction with the Choice of Renewable Heating System?}

The interviews demonstrate an important influence of homeowner-installer interactions on homeowners' attitudes towards the installed renewable heating system (Section 4.3), which is in accordance with findings from the literature (Section 2.4). Homeowners are more likely to be satisfied with their decision when they have had a positive experience with the installer, both during the installation and post-installation periods. During the installation period, homeowners form an opinion about the competency of installers, based on installer behavior (e.g., expressed or lacking confidence in technical manipulations) and communication skills (e.g., willingness and capacity to explain how to operate the system). Both the quality of the explanation during the installation process and the quality of the after-sale services provided by installers can impact homeowners' perception of their heating systems, by making homeowners feel either at ease or uncomfortable with the operation and setting of the system.

Homeowners share their experience, both positive and negative, within their social circles. Providing high-quality installation services, accompanied with effective installerhomeowner communication, can be seen as an opportunity for installers to build trust with homeowners. This can not only result in establishing a long-term relationship with the homeowners who are already the installers' clients (e.g., maintenance contracts, further replacements), but is likely to also facilitate finding new clients and expanding the business.

\subsection{How Could Installers Be Included in Renewable Heating Programs with the Objective of Increasing Renewable Heating Technology Uptake?}

The case study has shown that many homeowners considered the utility-operated program on renewable heating systems as neutral and trustable, and that they used the recommendations provided by the program to choose their installers (Sections 4.2 and 4.4). This demonstrates the importance for the renewable heating programs to go beyond providing subsidies and running awareness campaigns for homeowners, by working closely with installers. The inclusion of installers should not be limited to trainings already provided by many programs [27], but should target the development of long-term partnerships, making use of feedback on the quality of installation services and on the effectiveness 
of the programs; this can be achieved by regular information and exchange events with installers, consumer and installer surveys, and field check-ups.

It might be important to incentivize installers to actively propose renewable heating solutions, by introducing quantitative criteria for the program partnership (for example, number of installations per year). However, it is also important for the energy programs to be flexible and work with non-partner installers in cases where they are chosen by the homeowners, and respect the equipment and installation quality criteria (Sections 4.2 and 4.4).

\subsection{Evaluation of Results}

The results of the case study should be treated with caution. We performed interviews with a small and rather homogeneous group of households, who installed heat pumps in single-family houses in Geneva. The results cannot be extrapolated to the entire population, but can serve as a basis for further research (e.g., quantitative study). It should be considered that we interviewed only those households who received subsidy from the Chaleur renouvelable program. There are the following other groups of households that could be studied: those who installed a heat pump but did not receive any subsidy; those who received a subsidy from another renewable energy program; those who considered installing a heat pump but chose a fossil-based system; finally, those who preferred the fossil-based system without considering renewable heating options. The fact that the study was organized by SIG may have also influenced the participation and answers of the households. In addition, some of our results may be location-specific.

Despite the above-mentioned limitations, the results of the case study, combined with the findings from the literature review, could be of interest for other locations, as they represent a contribution to understanding the decision processes that are related to the uptake of renewable heating technologies [26]. Our approach has a number of advantages. We investigated real cases of heat pump adoption, while most research is conducted with questionnaires based on hypothetical situations [12,16,22-25]. We obtained a deeper insight into the information sources and criteria that are used by households to choose their installer (Section 4.2), and we better understood how "installer-household" interactions impact household satisfaction with the heat pump system (Section 4.3). We also gained a deeper insight into the household practices of participation in energy programs (Sections 4.4 and 4.5).

\section{Conclusions and Recommendations}

In this study, we performed a detailed literature review on the views, decision process, and experience of homeowners, with regard to renewable heating systems, and investigated the real case of heat pump adoption in single-family houses in Geneva, supported by the local renewable energy program Chaleur renouvelable. We showed a variety of homeowner practices and attitudes, with regard to the choice and use of heat pump systems, and we analyzed the role of installers and renewable energy programs. Some general conclusions can be drawn.

The results clearly indicated that the decision to change a heating system is strongly related to the system's age and condition, and it is rather difficult to motivate homeowners to take action before they have to do so anyway for technical reasons. Indeed, very few of them decided to change the heating system voluntary, for either economic or comfort reasons. We confirmed that there are exchanges and discussions about such decisions within social circles, and that the reputation of a renewable energy technology is an important factor influencing its uptake. We also found that installers play a crucial role in assuring homeowner satisfaction and conveying a good image of technology. This includes the quality of the chosen equipment, installation and settings, communication, and after-sale services. The results highlighted the following preferences of the households when choosing their installers: (1) reliability-the installer was approved by a neutral and trustable party; (2) previous experience-the installer was advised by a member of social circles, or was known before; (3) economic - the installer made an offer free of charge, or 
their offer was the least expensive. As a further finding, support provided by renewable energy programs should not be limited to subsidies. Homeowners declared difficulties in choosing installers, and appreciated the advice offered by a neutral and trustable third party. Therefore, renewable energy programs can successfully take up this task by creating partnerships with highly qualified installers, and recommending them to the households. The programs can contribute to the rising quality of installer services, by providing training support and carefully selecting partner companies (including the precondition of already having installed well-functioning renewable heating systems, and regular monitoring of the installations). The active promotion of renewable heating technologies by installers is very important, given their impact on homeowner decisions and general inertia in homeowner choice of heating systems. Therefore, installers should be motivated to sell renewable heating systems, which is not always the case in practice (according to the experience made in Chaleur renouvelable, many installers still prefer fossil-based systems as they are easier to install). Indeed, a very important result is the general appreciation of heat pump technology by households, both for comfort and environmental reasons, and ease of use, while those who complained did so mainly because of installation problems.

More broadly, we conclude that, in order to foster market transformation towards renewable heating systems, program operators should not only aim to influence individual homeowners (to whom they give subsidies), but also society in general. For instance, households could also be assisted in cases when they have problems with installed renewable heating systems. Program operators could initiate site visits and provide free-of-charge repair services (as has been done within Chaleur renouvelable program). While such an approach represents additional costs for the program operator, it can help to resolve individual problems, avoid reputational damage to novel renewable energy technologies, and facilitate their diffusion, leveraged by social exchanges. Following such a pro-active approach, program operators can help to pinpoint the main challenges that should be taken into account in the training of professionals and when accrediting installers. Also, administrative procedures for obtaining subsidies should be simple and not require complex application procedures before installing the heating system (often the heating systems are replaced in a hurry and homeowners have no time to wait for a decision about the subsidy). It is hence important that installers are well aware about the program requirements, including the choice of equipment. They can use subsidies as a sales argument. Moreover, streamlined procedures can help to attract households that would otherwise refuse to install a renewable heating system, due to time constraints. In addition, program operators can assist households in evaluating their choice of a heating system, by providing tools for pre-qualification and ex-post analysis. As an example, Chaleur renouvelable developed a web-based simulator, allowing the preparation of a comparative analysis of different heat supply options, with regard to annual heating costs (accounting for initial investment costs, energy and maintenance costs), environmental impacts $\left(\mathrm{CO}_{2}\right.$ emissions), and subsidies (based on the amount of $\mathrm{CO}_{2}$ savings). Depending on the locally available energy resources, renewable energy programs can hence offer impartial advice (e.g., by assisting households in choosing among the offers), or act as a mediator (e.g., in the case of conflicts). In the operational phase, programs can assist households in reducing their energy consumption by means of tailored information, including adapted printed manuals/brochures on heat pump technology, advice via web sites/phone lines, and seminars.

The social interactions between households, as well as between households and installers, seem to be significant catalysts for change-suggesting that more research is advisable in order to better understand decision-making processes within social contexts. As further steps, we recommend conducting larger-scale surveys with the objective of basing the analysis on a significant number of households (ideally located in different cities), which will test and enrich the conclusion. Apart from decision making related to single-family houses, the inhabitants and the owners of multi-family houses should also be studied. 
Author Contributions: Conceptualization, A.F. and M.K.P.; methodology, A.F., M.R. and M.K.P.; validation, M.R., M.B. and M.S.; formal analysis and investigation, A.F.; writing-original draft preparation, A.F. and M.K.P.; writing—review and editing, S.C.; visualization, S.C.; supervision, M.K.P.; funding acquisition, M.K.P. All authors have read and agreed to the published version of the manuscript.

Funding: This work was co-funded by Services Industriels de Genève (SIG) in the context of their support of the Chair for Energy Efficiency at University of Geneva. The research represents a complementary activity by University of Geneva in the context of the Swiss Competence Center for Research in Energy, Society and Transition (SCCER-CREST) and the Swiss Competence Center for Energy Research on Future Energy Efficient Buildings \& Districts (SCCER FEEB\&D), which are both funded by the Swiss Innovation Agency Innosuisse. The views expressed by the authors do not necessarily reflect the views of SIG or any other organization.

Institutional Review Board Statement: Not applicable.

Informed Consent Statement: Informed consent was obtained from all subjects involved in the study.

Data Availability Statement: Not applicable.

Acknowledgments: We would like to thank Cédric Jeanneret, Marcel Ruegg and Pascale le Strat (all with SIG) for providing information and advice.

Conflicts of Interest: The authors declare no conflict of interest.

\section{Abbreviations}

Greenhouse gases (GHG); Services Industriels de Genève (SIG).

\section{Appendix A}

Table A1. Interview guide.

\begin{tabular}{|c|c|}
\hline \multicolumn{2}{|r|}{ Checking the Information Available } \\
\hline $\begin{array}{l}1 \\
2 \\
3 \\
4 \\
5\end{array}$ & $\begin{array}{l}\text { Type of heating system using renewable energy } \\
\text { Year and month of installation } \\
\text { Time period of construction of the house } \\
\text { Type of previous heating system } \\
\text { Postal code of the house }\end{array}$ \\
\hline \multicolumn{2}{|r|}{ Heating System and Installer } \\
\hline 6 & Why did you decide to change your heating system? \\
\hline $\begin{array}{l}7 \\
7.1 \\
7.2 \\
7.3\end{array}$ & $\begin{array}{c}\text { How did you choose your new heating system? } \\
\text { How did you go about it? } \\
\begin{array}{c}\text { Where did you look for information about your new heating system? E.g., looking in brochures/internet/newspapers, asking } \\
\text { friends who had changed heating systems, asking companies, etc. } \\
\text { Which source of information was most/least useful? }\end{array}\end{array}$ \\
\hline $\begin{array}{l}8 \\
8.1 \\
8.2 \\
8.3\end{array}$ & $\begin{array}{c}\text { Why did you choose this type of heating system (heat pump vs. gas or oil boiler)? } \\
\text { What were the criteria for choice? For example: energy price, environmental impact of the heating system, advanced technology, } \\
\text { etc. } \\
\text { Was sufficient information available? } \\
\text { Did you have to ask friends or professionals? }\end{array}$ \\
\hline $\begin{array}{c}9 \\
9.1 \\
9.2\end{array}$ & $\begin{array}{c}\text { How did you choose your installer? } \\
\text { Was this installer recommended to you? By whom? } \\
\text { What role did the installer play in your choice of heating system (heat pump instead of gas or oil boiler)? }\end{array}$ \\
\hline $\begin{array}{l}10 \\
10.1 \\
10.2 \\
10.3 \\
10.4\end{array}$ & $\begin{array}{c}\text { Once the heating system was installed, how did the installer explain the operation of your heating system? } \\
\text { What did you particularly like about it? } \\
\text { What did you like less? } \\
\text { Was the information available sufficient? Did you look for information elsewhere? } \\
\text { Are you satisfied with your installer? }\end{array}$ \\
\hline $\begin{array}{l}11 \\
11.1 \\
11.2 \\
11.3\end{array}$ & $\begin{array}{c}\text { Do you feel at ease using your heating system? } \\
\text { If you have any questions, whom can you contact? } \\
\text { What do you particularly like about your heating system? } \\
\text { What do you like less? }\end{array}$ \\
\hline
\end{tabular}


Table A1. Cont.

\begin{tabular}{cc}
\hline 12 & Have you estimated how your expenses on heating have changed since the installation of your new heating system? \\
12.1 & What do you think about this change? Are you satisfied? \\
12.2 & If you have any questions, whom can you contact? \\
\hline 13 & Overall, are you satisfied with your new heating system? \\
13.1 & Why or why not? \\
13.2 & If you could improve a few things what would you do? \\
13.3 & Have you spoken to your friends about this new heating system? \\
\hline
\end{tabular}

"Renewable Heat" Program (“Chaleur renouvelable" Program)

\begin{tabular}{cc}
\hline 14 & How did you learn about the Renewable Heat Program ("Chaleur renouvelable" program)? \\
14.1 & Was it the installer who suggested to request subsidies or was it yourself? \\
14.2 & Where did you find the information? \\
14.3 & Who told you about it? \\
\hline
\end{tabular}

15 What do you remember from this program?

15.1

Was the information clear? E.g., the conditions for participation, the administrative procedures to be followed, the deadlines, the

amount of the subsidy, etc.
Did you do the paperwork or did the installer take care of it?

15.2

15.3

15.4

16

16.1

16.2

17

17.1

18

18.1

18.2

19

Have you taken any other energy efficiency measures besides installing your new heating system? E.g., Change in windows, roof

What did you find particularly interesting about the information you received?

Do you have any suggestions for improvement?

Which of the advantages of replacing your boiler with the "Renewable Heat" program ("Chaleur renouvelable" program) were you most interested in?

What did you particularly like about the program?

Which of the advantages did you find most important (subsidies, heating contractor approved by SIG)? Why or why not?

If you had not obtained the subsidy from the "Renewable Heat" program ("Chaleur renouvelable" program), would you have installed this type of heating system?

Why or why not? How important was the program for the choice of the type of heating system?

How did you finance the part of the costs of your new heating system that was not covered by the subsidy?

For example, through savings or borrowing?

By other types of support: cantonal subsidies from the Cantonal Energy Office/tax deductions/energy advice from the Cantonal Energy Office/other financial incentives/other non-financial support.

\section{Additional Questions (if you Have Time)}

19.1

19.2 When you made these changes, did you also apply for subsidies from the canton, SIG or another party? And did you rece
19.3 Do you have any plans to do so in the future? Will you apply for other types of support (subsidies, etc.)? insulation, wall insulation, energy audit, energy advice from the cantonal energy office.

Did you make any other changes before or after replacing your heating system?

20 Do you or anyone in your household monitor your energy and water consumption in your home? E.g., Electricity, Heating, Water. 20.1 Why?

There are currently various proposals for billing energy. Some propose to finance the development of renewable energies and 21 others to compensate for $\mathrm{CO}_{2}$ emissions through a supplement included in the tariff. Do you prefer the most economical or the 21.1 most ecological rate?

21.1 Why or why not?

\begin{tabular}{|c|c|}
\hline \multicolumn{2}{|r|}{ SIG Data } \\
\hline 22 & What is the electricity tariff you currently have? \\
\hline a & Initial \\
\hline $\mathrm{b}$ & Vitale Blue \\
\hline $\mathrm{C}$ & Offre Découverte (translated: “Discovery Offer") \\
\hline $\mathrm{d}$ & Offre Horizon (translated: "Horizon Offer") \\
\hline $\mathrm{e}$ & Vitale Vert \\
\hline $\mathrm{f}$ & I don't know \\
\hline \multicolumn{2}{|r|}{ Socio-Economic Data } \\
\hline 23 & How many people are living in your household? \\
\hline 24 & What is your age group? What is your age group and that of the other members of your household? \\
\hline 25 & Which category best describes your work situation? As well as that of the other members of the household? \\
\hline a & Employed full-time \\
\hline $\mathrm{b}$ & Employed part-time \\
\hline $\mathrm{C}$ & Self-employed \\
\hline $\mathrm{d}$ & Unemployed \\
\hline $\mathrm{e}$ & Retired \\
\hline $\mathrm{f}$ & Student \\
\hline $\mathrm{g}$ & House wife/husband \\
\hline h & I prefer not to say \\
\hline $\mathrm{i}$ & Other. \\
\hline 26 & In which professional field do you work or have you worked? And the other members of your household? \\
\hline
\end{tabular}




\section{Appendix B}

Table A2. Participant profiles.

\begin{tabular}{|c|c|c|c|c|c|c|c|c|c|c|}
\hline $\begin{array}{l}\text { Interview } \\
\text { Number }\end{array}$ & $\begin{array}{c}\text { Heating } \\
\text { Before }\end{array}$ & $\underset{\text { Installed }}{\text { Heap Pump }}$ & $\begin{array}{l}\text { Installer } \\
\text { ID }\end{array}$ & $\begin{array}{l}\text { Installer } \\
\text { Partnership } \\
\text { Status }\end{array}$ & $\begin{array}{l}\text { Year of Heap } \\
\text { Pump } \\
\text { Installation }\end{array}$ & $\begin{array}{c}\text { Year of } \\
\text { Building } \\
\text { Construction }\end{array}$ & $\begin{array}{l}\text { Household } \\
\text { Size }\end{array}$ & Description & $\begin{array}{l}\text { Professional } \\
\text { Situation }\end{array}$ & Professional Field \\
\hline 1 & Electricity & $\begin{array}{l}\text { Ground- } \\
\text { source }\end{array}$ & A & Excluded & 2014 & 1986-1990 & 2 & Couple, both 60 years old & $\begin{array}{l}\text { Husband } \\
\text { entrepreneur, wife } \\
\text { retired }\end{array}$ & $\begin{array}{l}\text { Husband humanitarian } \\
\text { and engineering, wife } \\
\text { humanitarian }\end{array}$ \\
\hline 2 & $\begin{array}{l}\mathrm{New} \\
\text { construction }\end{array}$ & Air-to-water & B & Non-partner & 2008 & 2008 & 3 & $\begin{array}{l}\text { Female } 66 \text { years old, her } \\
\text { daughter } 29 \text { years old and } \\
\text { son } 38 \text { years old. }\end{array}$ & $\begin{array}{l}\text { Mother retired, } \\
\text { daughter and son } \\
\text { employed }\end{array}$ & $\begin{array}{l}\text { Mother tailoring and } \\
\text { commerce, daughter social } \\
\text { work; son security }\end{array}$ \\
\hline 3 & Electricity & Air-to-water & $\mathrm{C}$ & Partner & 2014 & 1967 & 2 & Couple, both 80 years old. & Retired & $\begin{array}{l}\text { Husband electrical } \\
\text { engineering, wife } \\
\text { housekeeping }\end{array}$ \\
\hline 4 & Heating oil & Air-to-water & $\mathrm{D}$ & Non-partner & 2015 & 1981-1985 & 1 & Male $>80$ years old. & Retired & Engineering \\
\hline 5 & Heating oil & Air-to-water & $\mathrm{A}$ & Excluded & 2013 & 1946-1960 & 1 & Male $70-80$ years old. & Retired & Industrial economy \\
\hline 6 & Electricity & Air-to-water & $\mathrm{E}$ & Non-partner & 2013 & 1988 & 1 & Female 68 years old. & Retired & Reception \\
\hline 7 & Electricity & Air-to-water & $\mathrm{E}$ & Non-partner & 2015 & 1988 & 1 & Female 85 years old. & Retired & Public relations \\
\hline 8 & Natural gas & Air-to-water & $\mathrm{F}$ & Partner & 2014 & 1986-1990 & 5 & $\begin{array}{c}\text { Couple } 50 \text { and } 43 \text { years old, } \\
\text { with children } 6,10 \text { and } \\
11 \text { years old. }\end{array}$ & $\begin{array}{c}\text { Husband } \\
\text { employed, wife } \\
\text { housewife }\end{array}$ & $\begin{array}{l}\text { Husband banking, wife } \\
\text { housekeeping }\end{array}$ \\
\hline 9 & Heating oil & Air-to-water & G & Partner & 2014 & 1961-1970 & 3 & $\begin{array}{l}\text { Couple both } 65 \text { years old, } \\
\text { their daughter } 30 \text { years old. }\end{array}$ & $\begin{array}{l}\text { Husband and wife } \\
\text { retired, daughter } \\
\text { employed }\end{array}$ & $\begin{array}{l}\text { Husband entrepreneurial, } \\
\text { wife science, daughter law }\end{array}$ \\
\hline 10 & Electricity & $\begin{array}{l}\text { Ground- } \\
\text { source }\end{array}$ & $\mathrm{H}$ & Partner & 2016 & 1981-1985 & 2 & Couple 63 and 68 years old. & $\begin{array}{l}\text { Husband retired, } \\
\text { wife employed }\end{array}$ & $\begin{array}{l}\text { Husband education (math } \\
\text { and physics), wife } \\
\text { informatics }\end{array}$ \\
\hline 11 & Heating oil & Air-to-water & I & Partner & 2016 & 1975 & 3 & $\begin{array}{l}\text { Couple } 60-70 \text { years old, } \\
\text { their son } 29 \text { years old. }\end{array}$ & $\begin{array}{l}\text { Husband and wife } \\
\text { retired, son } \\
\text { employed }\end{array}$ & $\begin{array}{c}\text { Husband insurance math, } \\
\text { wife informatics, son } \\
\text { statistics }\end{array}$ \\
\hline 12 & Heating oil & Air-to-water & I & Partner & 2014 & 1974-1975 & 2 & Couple, both 77 years old. & Retired & $\begin{array}{c}\text { Family business } \\
\text { (climatization and } \\
\text { ventilation) }\end{array}$ \\
\hline 13 & Heating oil & Air-to-water & A & Excluded & 2014 & $1961-1970$ & 1 & Female 79 y.o. & Retired & Secretariat \\
\hline 14 & Heating oil & Air-to-water & A & Excluded & 2014 & 1996-2000 & 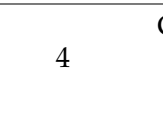 & $\begin{array}{c}\text { Couple } 58 \text { and } 54 \text { years old, } \\
\text { their daughters } 20 \text { and } \\
23 \text { years old. }\end{array}$ & $\begin{array}{c}\text { Husband and wife } \\
\text { employed, } \\
\text { daughters students }\end{array}$ & $\begin{array}{l}\text { Husband and wife } \\
\text { education, daughters } \\
\text { studying }\end{array}$ \\
\hline 15 & Natural gas & $\begin{array}{l}\text { Ground- } \\
\text { source }\end{array}$ & $\mathrm{J}$ & Partner & 2015 & 1991-1995 & 2 & Couple 75 and 64 years old. & Retired & $\begin{array}{c}\text { Husband insurance, wife } \\
\text { secretariat }\end{array}$ \\
\hline
\end{tabular}




\section{References}

1. IRENA. Renewable Energy Target Setting; International Renewable Energy Agency: Geneva, Switzerland, 2015.

2. EC. Communication from the Commission to the European Parliament, the Council, the European Economic and Social Committee and the Committee of the Regions; European Commission, Ed.; Energy Roadmap: Brussels, Belgium, 2011.

3. EC. The 2020 Climate and Energy Package; Commission, E., Ed.; European Commission: Brussels, Belgium, 2014.

4. EC. 2030 Framework for Climate and Energy Policies; Commission, E., Ed.; European Commission: Brussels, Belgium, 2014.

5. SFOE. Energy Strategy 2050. What It Energy Strategy 2050? Swiss Federal Office of Energy. 2019. Available online: http: / / www.bfe.admin.ch/energiestrategie2050/06445/index.html?lang=en (accessed on 27 July 2021).

6. Swiss Federal Council. Federal Act on the Reduction of CO2 Emissions 641.71. The Federal Council. 2011. Available online: https: / / www.admin.ch/opc/fr/classified-compilation/20091310/201301010000/641.71.pdf (accessed on 27 July 2021).

7. IEA. World Energy Outlook 2016. International Energy Agency. 2016. Available online: http://www.worldenergyoutlook.org/ publications / weo-2016/ (accessed on 27 July 2021).

8. IEA. Tracking Clean Energy Progress 2017. Energy Technology Perspectives 2017 Excerpt Informing Energy Sector Transformations. International Energy Agency. 2017. Available online: https:/ /www.iea.org/publications/freepublications/publication/ TrackingCleanEnergyProgress2017.pdf (accessed on 27 July 2021).

9. Kennedy, M.; Basu, B. A study on the implementation of renewable heating technologies in the domestic sector in Ireland with implications on consumers' decision-making. J. Clean. Prod. 2013, 44, 133-142. [CrossRef]

10. Connor, P.; Bürger, V.; Beurskens, L.; Ericsson, K.; Egger, C. Devising renewable heat policy: Overview of support options. Energy Policy 2013, 59, 3-16. [CrossRef]

11. Isaksson, C.; Ellegård, K. Anchoring energy efficiency information in households' everyday projects: Peoples' understanding of renewable heating systems. Energy Effic. 2015, 8, 353-364. [CrossRef]

12. Michelsen, C.C.; Madlener, R. Homeowners' preferences for adopting innovative residential heating systems: A discrete choice analysis for Germany. Energy Econ. 2012, 34, 1271-1283. [CrossRef]

13. Friege, J.; Chappin, E. Modelling decisions on energy-efficient renovations: A review. Renew. Sustain. Energy Rev. 2014, 39, 196-208. [CrossRef]

14. EC. Proposal for a Directive of the European Parliament and of the Council on Energy Efficiency (Recast); European Commission: Brussels, Belgium, 2021.

15. Decker, T.; Menrad, K. House owners' perceptions and factors influencing their choice of specific heating systems in Germany. Energy Policy 2015, 85, 150-161. [CrossRef]

16. Karytsas, S.; Theodoropoulou, H. Public awareness and willingness to adopt ground source heat pumps for domestic heating and cooling. Renew. Sustain. Energy Rev. 2014, 34, 49-57. [CrossRef]

17. Bjørnstad, E. Diffusion of renewable heating technologies in households. Experiences from the Norwegian Household Subsidy Programme. Energy Policy 2012, 48, 148-158. [CrossRef]

18. Michelsen, C.C.; Madlener, R. Homeowner satisfaction with low-carbon heating technologies. J. Clean. Prod. 2017, 141, 1286-1292. [CrossRef]

19. Martiskainen, M.; Schot, J.; Sovacool, B. User innovation, niche construction and regime destabilization in heat pump transitions Environ. Innov. Soc. Transit. 2021, 119-140. [CrossRef]

20. Wade, F.; Hitchings, R.; Shipworth, M. Understanding the missing middlemen of domestic heating: Installers as a community of professional practice in the United Kingdom. Energy Res. Soc. Sci. 2016, 19, 39-47. [CrossRef]

21. Owen, A.; Mitchell, G. Outside influence-Some effects of retrofit installers and advisors on energy behaviours in households. Indoor Built Environ. 2015, 24, 925-936. [CrossRef]

22. Michelsen, C.C.; Madlener, R. Motivational factors influencing the homeowners' decisions between residential heating systems: An empirical analysis for Germany. Energy Policy 2013, 57, 221-233. [CrossRef]

23. Sopha, B.M.; Klöckner, C.A. Psychological factors in the diffusion of sustainable technology: A study of Norwegian households adoption of wood pellet heating. Renew. Sustain. Energy Rev. 2011, 15, 2756-2765. [CrossRef]

24. Scarpa, R.; Willis, K. Willingness-to-pay for renewable energy: Primary and discretionary choice of British households' for micro-generation technologies. Energy Econ. 2010, 32, 129-136. [CrossRef]

25. Rouvinen, S.; Matero, J. Stated preferences of Finnish private homeowners for residential heating systems: A discrete choice experiment. Biomass Bioenergy 2013, 57, 22-32. [CrossRef]

26. Hecher, M.; Hatzl, S.; Knoeri, C.; Posch, A. The trigger matters: The decision-making process for heating systems in the residential building sector. Energy Policy 2017, 102, 288-306. [CrossRef]

27. Mahapatra, K. Leif Gustavsson. Diffusion of Energy-Saving Innovative Heating Systems in Sweden: A Consumer Survey Approach. In Proceedings of the ACEEE 2006 Summer Study on Energy Efficiency in Buildings, Pacific Grove, CA, USA, 13 August 2006; pp. 203-215.

28. Sopha, B.M.; Klöckner, C.A.; Hertwich, E.G. Adoption and diffusion of heating systems in Norway: Coupling agent-based modeling with empirical research. Environ. Innov. Soc. Transit. 2013, 8, 42-61. [CrossRef] 
29. Willis, K.; Scarpa, R.; Gilroy, R.; Hamza, N. Renewable energy adoption in an ageing population: Heterogeneity in preferences for micro-generation technology adoption. Energy Policy 2011, 39, 6021-6029. [CrossRef]

30. Wade, F.; Shipworth, M.; Hitchings, R. How installers select and explain domestic heating controls. Build. Res. Inf. 2017, 45, 371-383. [CrossRef]

31. Skjevrak, G.; Sopha, B.M. Wood-Pellet Heating in Norway: Early Adopters' Satisfaction and Problems That Have Been Experienced. Sustainability 2012, 4, 1089. [CrossRef]

32. Gleeson, C.P. Residential heat pump installations: The role of vocational education and training. Build. Res. Inf. 2016, 44, 394-406. [CrossRef]

33. Lillemo, S.C.; Alfnes, F.; Halvorsen, B.; Wik, M. Households' heating investments: The effect of motives and attitudes on choice of equipment. Biomass Bioenergy 2013, 57, 4-12. [CrossRef]

34. Mahapatra, K.; Gustavsson, L. An adopter-centric approach to analyze the diffusion patterns of innovative residential heating systems in Sweden. Energy Policy 2008, 36, 577-590. [CrossRef]

35. Mahapatra, K.; Gustavsson, L. Innovative approaches to domestic heating: Homeowners' perceptions and factors influencing their choice of heating system. Int. J. Consum. Stud. 2008, 32, 75-87. [CrossRef]

36. Mahapatra, K.; Gustavsson, L. Influencing Swedish homeowners to adopt district heating system. Appl. Energy 2009, 86, 144-154. [CrossRef]

37. Mahapatra, K.; Gustavsson, L.; Nair, G. Swedish homeowners' perceptions of innovative heating systems-Results of three surveys. In Proceedings of the ECEEE 2009 Summer Study, La Colle sur Loup, France, 2 June 2009.

38. Mahapatra, K.; Gustavsson, L. Adoption of innovative heating systems-Needs and attitudes of Swedish homeowners. Energy Effic. 2010, 3, 1-18. [CrossRef]

39. Lowe, R.; Summerfield, A.; Oikonomou, E.; Love, J.; Biddulph, P.; Gleeson, C.; Chiu, L.F.; Wingfield, J. Final Report on Analysis of Heat Pump Data from the Renewable Heat Premium Payment (RHPP) Scheme; UCL Energy Institute: London, UK, 2017.

40. Kircher, K.J.; Zhang, K.M. Heat purchase agreements could lower barriers to heat pump adoption. Appl. Energy 2021, 286. [CrossRef]

41. Sopha, B.M.; Klöckner, C.A.; Skjevrak, G.; Hertwich, E.G. Norwegian households' perception of wood pellet stove compared to air-to-air heat pump and electric heating. Energy Policy 2010, 38, 3744-3754. [CrossRef]

42. Michelsen, C.C.; Madlener, R. Switching from fossil fuel to renewables in residential heating systems: An empirical study of homeowners' decisions in Germany. Energy Policy 2016, 89, 95-105. [CrossRef]

43. Mundaca, L.; Neij, L.; Worrell, E.; McNeil, M. Evaluating Energy Efficiency Policies with Energy-Economy Models. Annu. Rev. Environ. Resour. 2010, 35, 305-344. [CrossRef]

44. Sahakian, M. Keeping Cool in Southeast Asia. Energy Consumption and Urban Air-Conditioning; Palgrave Macmillan: London, UK, 2014.

45. Wilhite, H.; Nakagami, H.; Masuda, T.; Yamaga, Y.; Haneda, H. A cross-cultural analysis of household energy use behaviour in Japan and Norway. Energy Policy 1996, 24, 795-803. [CrossRef]

46. Woersdorfer, J.S.; Kaus, W. Will nonowners follow pioneer consumers in the adoption of solar thermal systems? Empirical evidence for northwestern Germany. Ecol. Econ. 2011, 70, 2282-2291. [CrossRef]

47. Rognon, F.; Yushchenko, A.; Rüetschi, M. Retrofitting fossil-based heating systems with air to water heat pumps in multifamily houses. In Proceedings of the 12th IEA Heat Pump Conference 2017, Rotterdam, The Netherlands, 16 May 2017.

48. Devine-Wright, P.; Wrapson, W.; Henshaw, V.; Guy, S. Low carbon heating and older adults: Comfort, cosiness and glow. Build. Res. Inf. 2014, 42, 288-299. [CrossRef]

49. Swiss Federal Council. Ordonnance sur la Réduction des émissions de CO2 641.711. The Federal Council. 2012. Available online: https:/ / www.admin.ch/opc/fr/classified-compilation/20120090/201306010000/641.711.pdf (accessed on 27 July 2021).

50. DETEC. Politique Climatique de la Suisse. Rapport Explicatif Relatif au Projet mis en Consultation. The Federal Department of the Environment, Transport, Energy and Communications (DETEC). 2016. Available online: https://www.admin.ch/ch/f/gg/ pc/documents /2801/Politique-climatique-de-la-Suisse-post-2020_Rapport-expl_fr.pdf (accessed on 27 July 2021).

51. INFRAS. Contributions Globales aux Cantons Selon l'Art. 15 LEne. Analyse de L'efficacité des Programes Cantonaux D'encouragement. Résultats de L'enquête; Swiss Federal Office of Energy: Geneva, Switzerland, 2016.

52. FOEN. Tableau 8. Émissions de gaz à effet de serre visées par la loi sur le CO2 et le Protocole de Kyoto, par secteur. Federal Office for the Environment. 2018. Available online: https:/ / www.bafu.admin.ch/bafu/fr/home/themes/climat/donnees-indicateurscartes / donnees / statistique-sur-le-co2.html (accessed on 27 July 2021).

53. Prognos. Der Energieverbrauch der Privaten Haushalte 2000-2016; BFE: Basel, Switzerland, 2017.

54. SIG. Chaleur Renouvelable. Services Industriels de Genève. 2016. Available online: http://www.sig-ge.ch/eco21/les-solutions/ particuliers / chaleur-renouvelable-pour-le-chauffage (accessed on 27 July 2021).

55. Vanden Borre, A. Definition of Heat Pumps and Their Use of Renewable Energy Sources. REHVA Journal. 2011. Available online: https:/ / www.rehva.eu/fileadmin/hvac-dictio/01-2012/04-2011/Definition_of_heat_pumps_and_their_use_of_ renewable_energy_sources.pdf (accessed on 27 July 2021).

56. XE. Currency Charts (EUR/CHF). XE. 2017. Available online: http://www.xe.com/currencycharts/?from=EUR\&to=CHF\& view=10Y (accessed on 27 July 2021). 
57. Achtnicht, M.; Madlener, R. Factors influencing German house owners' preferences on energy retrofits. Energy Policy 2014, 68, 254-263. [CrossRef]

58. Gram-Hanssen, K. Residential heat comfort practices: Understanding users. Build. Res. Inf. 2010, 38, 175-186. [CrossRef]

59. Abreu, M.I.; Oliveira, R.; Lopes, J. Attitudes and Practices of Homeowners in the Decision-making Process for Building Energy Renovation. Procedia Eng. 2017, 172, 52-59. [CrossRef]

60. Bickerstaff, K.; Devine-Wright, P.; Butler, C. Living with low carbon technologies: An agenda for sharing and comparing qualitative energy research. Energy Policy 2015, 84, 241-249. [CrossRef]

61. DemoSCOPE. Demoscope Market Research Company Website. DemoSCOPE. 2016. Available online: https://www.demoscope. ch/en/ (accessed on 27 July 2021).

62. Ritchie, J.; Lewis, J.; Nicholls, C.M.; Ormston, R. Qualitative Research Practice: A Guide for Social Science Students and Researchers; Sage: London, UK, 2013.

63. SIG. La gamme Electricité Vitale: Choisissez la qualité de votre électricité. Services Industriels de Genève. 2016. Available online: http:/ / www.sig-ge.ch/particuliers/les-energies/mon-electricite/les-produits-electricite-sig/les-produits-electricite-SIG (accessed on 27 July 2021). 